\title{
Fluctuations in the indoor environment in Spanish rural churches and their effects on heritage conservation: hygro-thermal and $\mathrm{CO}_{2}$ conditions monitoring
}

M.J. Varas-Muriel ${ }^{\mathrm{a}, \mathrm{b},}$ *, R. Fort ${ }^{\mathrm{a}}$, M.I. Martínez-Garrido ${ }^{\mathrm{a}, \mathrm{c}}$, A. Zornoza-Indart ${ }^{\mathrm{a}}$, P. López-Arce ${ }^{\text {a }}$

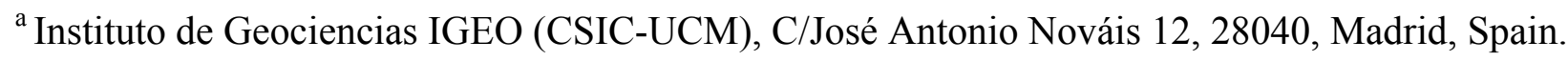

${ }^{\mathrm{b}}$ Departamento de Petrología y Geoquímica, Facultad Ciencias Geológicas, Universidad

Complutense de Madrid (UCM), C/José Antonio Nováis 12, 28040, Madrid, Spain.

${ }^{\mathrm{c}}$ CEI - Moncloa, (UCM-UPM, CSIC), Madrid, Spain.

* E-mail address: mjvaras@geo.ucm.es

Tf- +34913944918 , Fax- +34915442535

\section{ABSTRACT}

The indoor environment and its natural dynamics in small Spanish historical churches such as the studied here depend on the variations of outdoor climate and the moisture dynamics of walls, built with different materials. Such indoor environments are impacted by local factors, which may put at risk the conservation of a church's cultural assets. Natural ventilation in spring, the presence of people and especially the wintertime use of ageing heating system induce substantial fluctuations in indoor environments primarily affecting the stability of relative humidity $(\mathrm{RH})$. $\mathrm{RH}$ is the physical parameter that can induce efflorescence as well as plaster blistering and detachment in its inside walls, drying and cracking in the timber and efflorescence and disgregation in the carved dolostone. Where the RH inside building is not high, as in the present case, natural and induced fluctuations may lower it considerably ( $<25 \%)$, which is detrimental to conservation and human well-being both. Human presence partially counters the steep declines in $\mathrm{RH}$ attributable to heating in winter and warm, dry summer weather, although the trade-off is a rise in $\mathrm{CO}_{2}$ levels inside the church. Heating induces substantial changes in the $\mathrm{T}$ and $\mathrm{RH}$ on the high altar and in the upper areas of the nave, while natural ventilation affects the RH at the base of the church and favours the elimination of $\mathrm{CO}_{2}$. The results obtained have allowed us to develop a series of recommendations that might be useful for the preventive conservation of such historic buildings, without compromising human comfort.

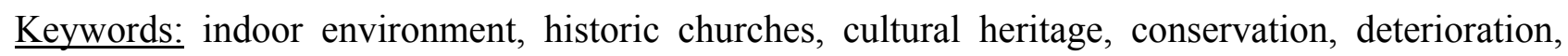
hygro-thermal conditions, fluctuations. 


\section{Introduction}

The natural indoor environment or historic indoor climate is defined as the hygro-thermal conditions (RH-T) prevailing inside a building throughout a representative period of its history [15]. The indoor environment tends to be more stable than the outdoor climate and to fluctuate less and more slowly. Under these temperature and humidity conditions, the materials comprising both the indoor elements (such as stone ashlars, clay-based materials, timber coffered ceilings, stuccos, deck slabs) and the works of art they enclose (sculptures, paintings, frescoes) adapt and become acclimated, and thus endure the passage of time [5-8].

The indoor environment depends primarily on the outdoor climate, building structure and dimensions, construction materials used and the hydrogeology of the underlying soil [9]. Interference is nonetheless inevitable, and may even generate artificial or induced microclimates with steep temperature $(\mathrm{T})$ and humidity $(\mathrm{RH})$ fluctuations that may destabilise the fragile balance between indoor climate and conservation of the artistic and architectural heritage $[1,4,5,7,10,11]$. Material surfaces are known to be affected by abrupt changes in environmental temperature and humidity, for these two parameters govern the most common types of decay, such as wet-dry cycles $[1,4,12]$, thermal shock [10] and surface or under-surface salt dissolution-crystallisation [13-15]. The ultimate consequence, known as material stress or fatigue, induces cracking, blistering, scaling, disaggregation and detachment in wall surfaces $[10,12]$. Moisture condensation may contribute to dissolving alkaline surfaces when the water vapour comes into contact with $\mathrm{CO}_{2}$ flowing into the church through open doors or generated by human metabolism, use of certain heating systems or lit candles or incense [12, 16, 17]. Carbonate (lime mortars or limestone) and sulfate (gypsum or cement mortars) dissolution releases anions and cations that are carried inward where they precipitate as salts $[14,15]$. Another result of surface condensation and damp (in the presence of high humidity and moderate temperatures) is biological colonisation by fungi, bacteria or even insects that may cause biodeterioration in certain areas of the building $[5,12,16]$.

The indoor conditions in historic buildings may be characterised by temperature and relative humidity values that run counter to human comfort $[12,18,19]$. Consequently, the main fluctuations in the indoor environment are can be attributed to human users, whose mere presence

alters the existing conditions and whose thermal comfort requires the use of environmental control systems [6-8, 12, 18, 20-22].

Many historical buildings (museums, theatres, palaces) have been studied in recent decades to establish requisites and strategies that would guarantee the protection and conservation of their indoor cultural assets, the well-being of their inhabitants, their energy efficiency and their economic 
sustainability. All those studies take as their point of departure a detailed understanding of the natural indoor environment and its variations in connection with any severe periodic alteration [3, 7, 11, 19-26]. These authors also showed that each building has its own specific indoor environment that depends on a host of local factors, precluding any possible generalisation in such studies.

Churches are among the most recent buildings to be addressed in this regard, since in countries with very cold and humid climates, the uncontrolled installation and use of heating systems beginning in the twentieth century have been shown to induce the deterioration of building interiors by adversely affecting their historic climates [4, 9, 10, 12, 20, 27, 28].

In Spain's cultural heritage, ninth- to nineteenth-century churches constitute a very numerous group of listed "historic-artistic monuments". In most cases, they are architectural gems of considerable historic and artistic worth. They are spread across the entire country, and are mainly found in rural areas. Throughout their history, these buildings have been reconstructed and rehabilitated in ways that have modified not only their appearance but also their indoor climate. In addition, heating began to be installed in many of these churches in the mid-twentieth century. The preference was for warm-air, intermittent systems, favoured for their low cost and speedy response, providing a comfortable indoor environment in short periods of time. In the absence of any regulation for this practice in such buildings until December 2012 (Spanish and European standard UNE-EN 15759-1) [29], heating systems were chosen in pursuit of users' thermal comfort, with no regard for the sustainable conservation of indoor church environments or their artistic assets [12].

San Juan Bautista Church (thirteenth-sixteenth centuries) at Talamanca de Jarama, a town $45 \mathrm{~km} \mathrm{N-}$ NE of Madrid, Spain is a representative example of such historic buildings. It has been a listed monument since 1931. While this church can seat up to 300 seated people, it is scantly occupied most of the year (50-150 people), with a full congregation normally only for services on significant religious holidays (Christmas, Easter, local festivities and so on). Normal mass hours consist of one service each on Friday and Saturday evenings and two on Sunday mornings. The low efficiency of its centralised and intermittent warm-air heating system installed in 1972 [30,31] has led to its mere occasional use for 1-2 $\mathrm{h}$ four to five times a week (Friday through Sunday; 5-6 h/week) from November through April. In recent years considerable moisture has been detected in its lower walls, with the concomitant rise in environmental humidity. As a result, the church is ventilated by opening its doors an average 10 hours daily.

The objectives pursued in the present study were, consequently: a) to characterise the type of natural environment prevailing inside a Spanish rural church, and its relationship to the outdoor climate and the associated conservation issues; b) to establish how natural ventilation, human presence and heating interfere with the natural dynamics of the indoor environment; and c) to 
determine whether the resulting alterations affect the decay of its inner walls and the deterioration of its artistic assets. Those data could be used to establish a series of recommendations for future action to control indoor hygro-thermal and $\mathrm{CO}_{2}$ conditions with a view to conserving the indoor heritage in small churches.

\section{Description of the church, the local climate and the heating system}

San Juan Bautista Church was built in the twelfth-thirteenth centuries (Romanesque style) with dolostone ashlars. It was reconstructed in the sixteenth century (Renaissance style) with rubble stone and mortar, brick and an earth fill (Fig. 1). The apse and presbytery (high altar) are all that remain of the original church. The main body or nave, enlarged in the sixteenth century, has a rectangular floor plan $(27 \times 12.5 \mathrm{~m})$ and is divided into three aisles with variable heights: $10.5 \mathrm{~m}$ in the middle aisle and $9 \mathrm{~m}$ in the two side aisles. The floor is $90 \mathrm{~cm}$ below the base of the high altar. The church lies at 30-50 cm below street level. The walls are $50 \mathrm{~cm}$ thick in the main body and 60 $\mathrm{cm}$ in the high altar. In 1885, when the church was in ruins, the south wall and bell tower were rebuilt, and a new choir was added over the west entrance. The present structure consequently has a $393 \mathrm{~m}^{2}$ footprint and contains $3952 \mathrm{~m}^{3}$ of air.

The church's most valuable indoor heritage elements include a Mudejar-style timber coffered ceiling, Romanesque ornamental dolostone carvings, primarily on the high altar, and a number of eighteenth century polychrome sculptures. These elements are highly sensitive to abrupt changes in humidity (wet-dry cycles) and the concomitant salt mobilisation and crystallisation.

The predominant stone, a yellow dolostone from nearby quarries [32], is found in ashlars, rough ashlars and ornaments of high altar (indoor and outdoor apse and presbytery), columns and arcades of main body and outdoor portals of south and west wall dados. This soft (105.2 $\pm 6.7 \mathrm{Mpa})$, porous (10-16\%), high water absorption $(5.6 \pm 1.4 \%)$ stone is readily workable but also highly susceptible to water and salt decay $[14,33]$. The indoor and outdoor stone surfaces are damaged around the base up to $40-50 \mathrm{~cm}$ due to rainwater filtration, capillary moisture and salt crystallisation.

The exterior masonry walls on the main body are very diverse, an indication of changing construction techniques between the sixteenth and nineteenth centuries. The north wall has irregular brick masonry on the corners and upper areas with rubble masonry panes in-between. The latter consist of small quartzite rocks and lime mortar, bordered by rows of brick. The north wall has a 53-cm high quartzite rubble stone, dolostone and lime mortar dado. On the more carefully designed south wall, the panes are filled with dolostone rubble and lime mortars surrounded by rows of brick. The dolostone ashlar dado on the south wall is $80-90 \mathrm{~cm}$ high. This wall has three small inwardly 
tapered windows. The indoor walls consist of earth with brick and assorted stone fragments. In the main body these masonry walls are fully plastered (gypsum mortas) and painted white. In the lower areas (up to 1.2-1.4 m), the plaster covers an uneven layer (5-7 cm thick) of cement mortar used to repair moisture-induced damage [34].

Because of the wide variety of constituent materials in these walls, water absorption is high (greater than in dolostone) and difficult to quantify. The lower quality north wall is at risk of rain- and windinduced decay, which increases moisture ingress (rainwater filtrations and capillary moisture) [34]. The higher quality south wall is in better condition, decayed only around the base where the moisture content is higher due to the presence of an outdoor stone dado (rainwater filtrations) and the below street level elevation of the indoor floor $(\sim 30 \mathrm{~cm}$, capillary moisture). In the upper areas, more exposed to solar radiation, the daily wet/dry cycles exacerbate seasonal evaporation and with it drying in this part of the wall. The differences in wall construction and the presence of inner moisture determine variations in the heat capacity of the materials and solar heat transfer, both between walls and within each at different heights [34].

The Talamanca de Jarama church, like many other historic churches, is characterised by low thermal and energy efficiency [30,31], due primarily to their architectural design and the traditional materials used in their construction $[1,12]$.

The local climate is Continental-Mediterranean, with the cold winters and hot summers typical of the inland Iberian Peninsula. The annual temperature fluctuations are upward of $20^{\circ} \mathrm{C}$, with scant (475 mm/year) and variable spring and autumn rainfall; i.e., the church is not located in a humid area. The town is located in a rural area where air quality is high (Category I [35]), with $\mathrm{CO}_{2}$ concentrations of 300-400 ppm [General Management for Environmental Assessment of the Region of Madrid].

The heating facility is a LIESCOTHERM OS/D-125 gas-oil unit with a power of $145.35 \mathrm{~kW}$, equipped with an automatic mechanical atomising burner. System autonomy is a mere 40 hours, while gas-oil consumption is $15 \mathrm{l} / \mathrm{h}$. It is a centralised, warm-air convection system in which the incoming outdoor air (north area) is rapidly heated to a pre-selected temperature of $45{ }^{\circ} \mathrm{C}$ and mixed with the indoor air. The rated hot-air flow is $9600 \mathrm{~m}^{3} / \mathrm{h}$ at $20^{\circ} \mathrm{C}$. The warm air is forced through four vents on the north wall, three at a height of $3 \mathrm{~m}$ in the north aisle, and one at a height of $2 \mathrm{~m}$ in the sacristy (Fig. 2). This facility was initially designed to deliver an environmental temperature of $15^{\circ} \mathrm{C}$ at a height of $1.5 \mathrm{~m}$. The flow of hot air forms two convective upward currents, one rising toward the upper part of the high altar and the other toward the upper SW corner of the main body. While with the heating on the temperature in the upper part of the church 
may rise by $7-8^{\circ} \mathrm{C}$, the increase at the base is no more than $1-2{ }^{\circ} \mathrm{C}[30]$. When the facility is turned off, it is cooled for 25 minutes with cold, damp outdoor air that flows inward through the same vents to be mixed with the hot, dry indoor air, abruptly modifying the conditions reached while the heating was on [30].

\section{Method}

Further to Bratasz and Kozlowski [4] recommendations and Spanish and European standard UNEEN 15759-1 [29], in this study the indoor and outdoor temperature (T), relative humidity (RH), dew point (DP) and absolute humidity (AbsHum) were monitored for 13 months (April 2011 to April 2012). Secundarily, the indoor $\mathrm{CO}_{2}$ levels were also measured in two 2-month unheated (AugustSeptember 2011) and heated (December 2011-January 2012) periods.

The indoor environment was monitored with three DS1923-F5 i-Button sensor grids, set for a logging frequency of 30 minutes (Fig. 3). Two grids were positioned in the nave of the church, one consisting of ten sensors placed underneath the pews $40 \mathrm{~cm}$ off the floor and the other of seven sensors positioned at heights of 3 or $5 \mathrm{~m}$ over the wood panels representing the stations of the cross $(3 \mathrm{~m})$ and in the choir $(5 \mathrm{~m})$. The third grid comprised four sensors on the high altar. Monitoring focused on the lower parts of the church $(<5 \mathrm{~m})$ where the effect of human presence is greatest. The DS1923 i-Button T/RH button-type sensor/loggers used had an operating range for temperature (T) of - 20 to $+85^{\circ} \mathrm{C}$ with 8 -bit $\left( \pm 0.5^{\circ} \mathrm{C}\right)$ resolution, and for relative humidity $(\mathrm{RH}), 0$ to $100 \%$ with 8-bit $( \pm 0.6 \%)$ resolution. Readings were logged and downloaded with 1-Wire Wiewer x64 software.

The outdoor environment conditions were also logged every 30 minutes with a 12-bit HOBO H8 ProSeries ONSET sensor, using BoxCar Pro-4 hardware for data logging and downloading. Operating range for temperature is $-30{ }^{\circ} \mathrm{C}$ to $+50{ }^{\circ} \mathrm{C}$ and for relative humidity, 0 to $100 \%$. This sensor was positioned on the bell tower, facing south (Fig. 3).

$\mathrm{CO}_{2}$ concentration inside the church was recorded every 30 minutes with a Hobo ${ }^{\circledR}$ Data Logger Telaire ${ }^{\circledR} 7001$ sensor (Fig. 3). Its measurement range is 0 to 10000 (in display) ppm and 0 to 4000 ppm (in datalogger recording) with a \pm 10 ppm accuracy or $\pm 5 \%$ of reading.

The $\mathrm{T}$ and RH findings were modelled with SURFER 8 software, used to maps the plan view and cross-sectional distribution of the indoor hygro-thermal conditions during different monitoring periods.

\section{Results}




\subsection{Relationship between indoor environment and outdoor climate}

The mean indoor environment and outdoor climate values were essentially similar in the period April 2011 to April 2012 (Table 1, Fig. 4). The mean temperature in both cases was $17^{\circ} \mathrm{C}$, with a similar mean range $\left(18-20^{\circ} \mathrm{C}\right)$. The low winter temperatures did not fall below freezing indoors or out, while the high summer temperatures in the upper area of the southwest corner of the church were over $34^{\circ} \mathrm{C}$ indoors and over $40{ }^{\circ} \mathrm{C}$ outdoors. At nearly $50 \%$, the $\mathrm{RH}$ was somewhat higher inside the church, where it fluctuated less widely than the outdoor value (25 compared to $50 \%$ ). The $\mathrm{W}$ area of the church ( $40 \mathrm{~cm}$ off the floor) consistently exhibited the minimum (summer, 15.6 \%) and maximum (spring, $93 \%$ ) indoor RH all year round. The maximum indoor RH values were recorded during the rainy months, November and April-May. The mean DP (dew point) was somewhat higher $\left(6.2^{\circ} \mathrm{C}\right)$ indoors than out, while the mean AbsHum (absolute humidity) values were very similar $\left(7 \mathrm{~g} / \mathrm{m}^{3}\right)$.

Of the three indoor areas monitored (pews or lower nave at $40 \mathrm{~cm}$, upper nave at 3-5 $\mathrm{m}$ and high altar), the pews had the highest mean RH (50\%) and lowest mean temperature $\left(17^{\circ} \mathrm{C}\right)$, while the upper nave mean $\mathrm{RH}$ and $\mathrm{T}$ were $47.5 \%$ and $18{ }^{\circ} \mathrm{C}$, respectively. Intermediate values were logged for the high altar: mean $\mathrm{RH}=49 \%$ and mean $\mathrm{T}=17.5^{\circ} \mathrm{C}$. The mean AbsHum values were the same in all three areas $\left(7.4 \mathrm{~g} / \mathrm{m}^{3}\right)$ and the mean DP was $0.5^{\circ} \mathrm{C}$ higher in the upper $\left(6.5^{\circ} \mathrm{C}\right)$ than in the lower nave. Since the temperatures were consistently higher than the dew point throughout the thirteen months of the study, no environmental moisture condensation was observed. The variations in the mean values of these environmental conditions in the three areas studied were similar across the year and comparable to the variations in the outdoor conditions (Fig. 4).

\subsection{Yearly variations in the indoor environment}

Throughout the thirteen-month monitoring period, the lowest mean low $\mathrm{T}$ and highest mean maximum $\mathrm{RH}$ were recorded in the pews $\left(40 \mathrm{~cm}\right.$ : $13.7^{\circ} \mathrm{C}$ and $67.5 \%$; Fig. 5), primarily in the NW area of the centre and north aisles. The mean low $\mathrm{T}$ and mean maximum RH and their patterns of variation throughout the year were similar in the upper nave $\left(15.3{ }^{\circ} \mathrm{C} ; 63 \%\right)$ and the high altar $\left(15.1^{\circ} \mathrm{C} ; 65.4 \%\right)$. On rainy days, however, the mean maximum $\mathrm{RH}$ in the high altar resembled the mean maximum $\mathrm{RH}$ in the pews.

Significant variations were observed in the mean high T and mean low RH for the last 6 months of the period, not only in terms of the mean yearly $\mathrm{T}$ and $\mathrm{RH}$, but also of the differences among the areas monitored (Fig. 5). Two clearly defined periods can be distinguished in the curves in Figure 5. No material differences between the mean indoor and outdoor $\mathrm{T}$ and $\mathrm{RH}$ values were recorded in 
the first period (April-October 2011). In the second period, however (November 2011 to April 2012), which concurred with indoor winter heating in the church, significant variations were observed in these variables, especially in the mean high $\mathrm{T}$.

\subsubsection{Indoor environment, April-October 2011}

In this first period, the indoor and outdoor mean $\mathrm{T}$ and $\mathrm{RH}$ varied concurrently (Fig. 5), although RH was slightly higher and $\mathrm{T}$ slightly lower indoors $\left(47 \% ; 21^{\circ} \mathrm{C}\right)$ than out $\left(43 \% ; 23{ }^{\circ} \mathrm{C}\right)$. The indoor mean high $\mathrm{T}$ and mean minimum $\mathrm{RH}$ curves likewise followed the same pattern as the indoor mean $\mathrm{T}$ and $\mathrm{RH}$, although with a few anomalies. Of the two observed on the temperature curve (Fig. 5b), one occurred in April when the mean high $\mathrm{T}$ in the nave was $3{ }^{\circ} \mathrm{C}(3-5 \mathrm{~m})$ or $4{ }^{\circ} \mathrm{C}$ $(40 \mathrm{~cm})$ higher on average than in the high altar. That difference concurred with the presence of a large congregation during the month's religious services (confirmation, Easter, novena and local festivities). The second temperature anomaly was recorded in June, when the mean high $\mathrm{T}$ in the upper nave and the high altar was 3 to $4{ }^{\circ} \mathrm{C}$ on average higher than in the pews. That anomaly may be attributed to the fact that the heating was turned on for maintenance during $1.5 \mathrm{~h}$, clearly affecting the mean high $\mathrm{T}$ for the month. The mean minimum RH values, in turn, exhibited a minor anomaly in April and May (Fig. 5a), when fairly small differences were detected between the mean minimum RH values for the nave (40\% at 3-5 $\mathrm{m}$ and $37.5 \%$ at $40 \mathrm{~cm}$ ) and the high altar (44\%). The mean minimum RH values were lowest in the lower nave when the church was full and the outdoor temperature was high and the outdoor RH low.

The indoor and outdoor values differed in the summer and especially in the spring, with lower $\mathrm{T}$ and higher RH values in the former (Fig. 6). Those differences affected the daily indoor temperature fluctuations $(\Delta \mathrm{T})$. Normally on the order of $1-1.5^{\circ} \mathrm{C} /$ day (Figs. 6a, $6 \mathrm{~b} 2$ and $6 \mathrm{~d}$ ), such fluctuations climbed to $2-4^{\circ} \mathrm{C} /$ day in the areas affected by the warm, dry outdoor air entering the church during the $10 \mathrm{~h}$ /day that the doors were opened for ventilation (Figs. 6b1 and 6c). Analogously, RH, which normally fluctuated $(\Delta \mathrm{RH})$ by $5-10 \%$ /day (more in the upper than in the lower nave) declined by up to $20-25 \%$ /day in areas exposed to daily ventilation, although only when the outdoor RH was substantially lower than the indoor value. After the doors were closed, however, the indoor RH returned to its initial value in less than $2 \mathrm{~h}$. Given the position of the doors (W and $\mathrm{S}$ ) and of the outdoor-connected heating system vents (NE), these T and RH fluctuations were most intense in the west and southwest pews (Fig. 6c) and the upper northeast zone (Fig. 6b1). These were also the areas with the highest $\mathrm{T}$ and lowest RH in this first 7-month period (SW and $\mathrm{W}=24-31{ }^{\circ} \mathrm{C}$ and 38 $16 \%$ and $\mathrm{NE}=20-29{ }^{\circ} \mathrm{C}$ and $23-18 \%$, whose values concurred with the conditions prevailing outside the church. 
In the spring, the RH fluctuated from $50 \%$ (warm, dry outdoor weather) and $70 \%$ (rainy weather), although values lying above and below this range were recorded in the areas affected by draughts (Figs. $6 \mathrm{~b} 1$ and $6 \mathrm{c} 1$ ). In the summer, the RH varied from 30 to $45 \%$, dipping to below $20 \%$ in the upper nave (3-5 m off the floor, Figs. $6 \mathrm{~b} 2$ and $6 \mathrm{~d} 2)$ and $50 \%$ in the pews $(40 \mathrm{~cm}$, Figs. $6 \mathrm{a} 2$ and $6 \mathrm{c} 2$ ). Temperatures were around $16-18^{\circ} \mathrm{C}$ throughout the spring with occasional 2 to $7-{ }^{\circ} \mathrm{C}$ rises in the pews (Figs. $6 \mathrm{~b} 1$ and $6 \mathrm{~d} 1$ ) and 1 to $3-{ }^{\circ} \mathrm{C}$ rises in the upper nave (Figs. $6 \mathrm{a} 1$ and $6 \mathrm{c} 1$ ), due to the presence of people during religious services. The summer $\mathrm{T}$ lay between 20 and $30{ }^{\circ} \mathrm{C}$, with occasional 2-3 ${ }^{\circ} \mathrm{C}$ rises in the pews (Figs. 6a2 and 6c2) when the congregation was present, and 5-7 ${ }^{\circ} \mathrm{C}$ rises in the upper nave (Figs. $6 \mathrm{~b} 2$ and $6 \mathrm{~d} 2$ ) on the day the heating was turned on. The AbsHum and DP remained constant at $8.6 \mathrm{~g} / \mathrm{m}^{3}$ and $9{ }^{\circ} \mathrm{C}\left(8 \mathrm{~g} / \mathrm{m}^{3}\right.$ and $8{ }^{\circ} \mathrm{C}$ outdoors $)$, respectively, until October. After that month, the T dipped to below $20{ }^{\circ} \mathrm{C}$ and the DP and RH began to rise with the rainy season. As the DP was consistently lower than the ambient T, however, no environmental moisture was observed to condense (Fig. 6).

$\mathrm{CO}_{2}$ concentration inside the church in August and September fluctuated from 400 to $600 \mathrm{ppm}$, while the mean concentration was $500.3 \mathrm{ppm}$. When the church was full during religious services (100-150 people/service), these values rose to $900-950 \mathrm{ppm}$, and sporadically to over $1200 \mathrm{ppm}$ (>300 people/service).

\subsubsection{Indoor environment, November 2011-April 2012}

In the second period, the indoor and outdoor mean $\mathrm{T}$ and $\mathrm{RH}$ followed different patterns of variation (Figs. 5a and b). The indoor mean $\mathrm{T}\left(11-12^{\circ} \mathrm{C}\right)$ was somewhat higher and more constant than the outdoor value $\left(10^{\circ} \mathrm{C}\right)$, while the mean outdoor $\mathrm{RH}(60 \%)$ was somewhat greater than the indoor humidity (54\%) during the rainy period from October to December 2011. That situation reversed (outdoor - $47 \%$ and indoor - 50 \%) from January to April 2012. The indoor mean high T and mean minimum RH curves, in particular the former, differed substantially from the indoor mean $\mathrm{T}$ and RH curves (Fig. 5b). The mean high $\mathrm{T}$ curves began to deviate away from the mean $\mathrm{T}$ curves in November. The $\mathrm{T}$ in the upper $(3-5 \mathrm{~m})$ nave and high altar deviated much more from the mean than the $\mathrm{T}$ in the lower $(40 \mathrm{~cm})$ nave.

The mean difference between the mean high $\mathrm{T}$ and the mean $\mathrm{T}$ during the first period was $3^{\circ} \mathrm{C}$ and during the second the gap widened, more in the upper nave and the high altar $\left(7-12^{\circ} \mathrm{C}\right)$ than in the lower nave $\left(3-6{ }^{\circ} \mathrm{C}\right)$. The mean minimum $\mathrm{RH}$ values for the lower nave differed similarly $(15-17 \%)$ from the mean RH throughout the 13 months of the survey (Fig. 5a), but the gaps were significantly wider (20-25\%) in the upper nave and the high altar. The lowest mean high $\mathrm{T}\left(12-13^{\circ} \mathrm{C}\right)$ and highest mean minimum RH (45-50\%) were found in the lower nave in these 6 months, whereas the 
highest mean high $\mathrm{T}\left(18-26^{\circ} \mathrm{C}\right)$ and lowest mean minimum $\mathrm{RH}(21-36 \%)$ were recorded in the upper nave, primarily in the SW, W and NE parts of the church. The values for the high altar were slightly lower than observed in the upper nave. These anomalies in the mean high $\mathrm{T}$ and mean minimum RH were attributed to the use of heating in the winter (November 2011-April 2012).

An anomaly detected in the December data was associated with the operation of the church's heating system for 22 consecutive hours (Fig. 5), which affected both the monthly mean $\mathrm{T}\left(1-2{ }^{\circ} \mathrm{C}\right.$ higher than normal) and monthly mean high $\mathrm{T}\left(6-7^{\circ} \mathrm{C}\right.$ higher than normal). The monthly mean and mean minimum RH also declined by $12-15 \%$ more than in the other winter months. The upper nave $(3-5 \mathrm{~m})$ and the high altar were affected most intensely. In that $22-\mathrm{h}$ period of constant heating, the upper nave RH tumbled $50 \%$ in the first $7 \mathrm{~h}$ and subsequently stabilised, holding at no lower than $30 \%$ for the remaining $15 \mathrm{~h}$. In the lower nave and the high altar, in contrast, the decline was gradual (10-14 and $30 \%$, respectively) throughout the period, and dropped to no lower than $40-45 \%$ and $35 \%$, respectively. The T rose steeply during those $22 \mathrm{~h}$, to upward of $25^{\circ} \mathrm{C}$ at $3-5 \mathrm{~m}$ off the floor, although only by $6-7^{\circ} \mathrm{C}$ in the pews (Table 2). Five hours after the heating was turned off, the RH recovered completely, although the entire heat gain was not lost: $\mathrm{T}$ fell by $9-10{ }^{\circ} \mathrm{C}$ in the upper nave, $2.5^{\circ} \mathrm{C}$ in the lower nave and $4.5^{\circ} \mathrm{C}$ in the high altar.

Figure $5 \mathrm{~b}$ also shows that while February was the coldest month in and outside the church, the lowest high temperatures $\left(14^{\circ} \mathrm{C}\right.$ in the lower nave and $17^{\circ} \mathrm{C}$ in the upper nave and in the high altar) were logged in January when the heating was used less frequently (Fig. 5b).

In this second period, daily church ventilation induced no significant fluctuations in indoor environmental conditions, which were similar to the outdoor conditions. The areas most affected by the ventilation (SW corner and $\mathrm{W}$ ) exhibited fluctuations of $1-1.5^{\circ} \mathrm{C} / \mathrm{day}(\Delta \mathrm{T})$, compared to the normal $0.5^{\circ} \mathrm{C} /$ day. Conversely, the RH not only failed to decline but even rose slightly indoors, for the outdoor RH was greater than or equal to the indoor values on rainy days. From November to January, the RH varied from 40 to $65 \%$ in the upper and from 45 to $70 \%$ in the lower nave (Figs. 6b3 and 6d3), and from February to April from 30 to $55 \%$ in the upper areas and from 35 to $60 \%$ in the pews (Figs. $6 \mathrm{~b} 4$ and 6d4). In the upper nave and the high altar, RH fluctuated more widely $(\Delta \mathrm{RH}=20-40 \%)$ and swiftly than in the pews $(\Delta \mathrm{RH}=10-20 \%)$ and than in the first period (April-October 2011). In the upper area, RH declined to 20-25\% and in the lower nave to 30-35\% (Figs. 6 and 7). These values were typical of the summer months, although then the declines were more gradual. In the winter, in contrast, with intermittent use of the heating, the decreases were abrupt and entailed very rapid subsequent rises (in just 1-2 h). The environmental $\mathrm{T}$ inside the church declined between November and January-February from $17-18{ }^{\circ} \mathrm{C}$ to $6-7^{\circ} \mathrm{C}$ in the upper nave and from $16-17$ to $4-5{ }^{\circ} \mathrm{C}$ in the pews. They subsequently turned upward, reaching $15{ }^{\circ} \mathrm{C}$ in the 
upper and $13{ }^{\circ} \mathrm{C}$ at in the lower nave in April 2012 (Fig. 6). The heating also induced wide temperature fluctuations, however, particularly in the upper nave (3-5 $\mathrm{m})$, where the $\mathrm{T}$ rose by up to 6-9 ${ }^{\circ} \mathrm{C}$ more than normal, although in the pews the rise was only $2-4{ }^{\circ} \mathrm{C}$ (Figs. 6 and 7). When the heating was turned off, these $\mathrm{T}$ declined rapidly to the natural values in $<1 \mathrm{~h}$. The DP declined from 12 to $-9{ }^{\circ} \mathrm{C}$ in February and then rose to $5-6^{\circ} \mathrm{C}$ in April (mean DP $=2.1{ }^{\circ} \mathrm{C}$ ), while the AbsHum was more constant, with a mean of $5.6 \mathrm{~g} / \mathrm{m}^{3}$. No condensation was observed in the inside environment or on wall surfaces at any time.

The $\mathrm{CO}_{2}$ concentration in the months of December 2011 and January 2012 scarcely varied with respect to the preceding period, ranging from 450 to $550 \mathrm{ppm}$, with a mean of $487.2 \mathrm{ppm}$. With a full congregation (on 25 December for instance; $>200$ people/service), the concentration fluctuated from 900 to $1000 \mathrm{ppm}$, while with fewer people present ( \pm 50 people/service), $\mathrm{CO}_{2}$ concentration declined to $600-750 \mathrm{ppm}$. Both readings were taken with the heating on. When the heating was on in the absence of people $(22 \mathrm{~h})$, the concentration ranged from 450 to $570 \mathrm{ppm}$.

\section{Discussion}

The indoor environment in San Juan Bautista Church at Talamanca de Jarama, Madrid, Spain, is heavily impacted by the outdoor climate (Fig. 5) and the thermal-hygrometric dynamics in its perimetric walls $[30,34]$. In-wall moisture and temperature conditions depend directly on the constituent materials and outdoor weather conditions, solar radiation and rain being the two factors that induce the widest fluctuations [34]. In this indoor environment, the natural dynamics cause the temperature and relative humidity to stratify obliquely, from the (colder and more damp) $\mathrm{N}$ wall to the (warmer and dryer) S wall, and from the chevet (NE and $\mathrm{E}$ areas), with a more stable environment, to the rear of the church (SW and W areas) where the conditions are less stable. This can be attributed to the effect of the moisture (rainwater filtration ans capillary moisture) in the walls of the main body to a height of $1.5 \mathrm{~m}$, rainwater filtrations along the entire north wall and intense evaporation in the south wall. No biodeterioration was detected in these areas.

This environment is altered in different ways and intensities by natural ventilation, heating and the presence of people.

Church ventilation, the result of its doors being open and the direct outdoor connection across the convection vents, generates fluctuations of some intensity when the differences between the indoor and outdoor conditions are substantial (high outdoor T and low outdoor RH) (Fig. 6). This occurs in the spring, for in the summer months the differences are smaller. The areas most intensely ventilated are the upper NE corner and the lower SW and W areas of the church. These fluctuations 
condition the dynamics of the natural indoor environment slightly in the spring, possibly destabilising the RH in the lower nave. The RH values are related to wet-dry cycles, salt dissolution-crystallisation-rehydration and plaster blistering at the base of the perimetric walls. Gypsum efflorescence and plaster blistering appear primarily in spring and summer, when the moisture in the walls declines under ventilation and the drying effect of the outdoor climate (solar radiation [34]).

The heating system destabilises the indoor conditions substantially for at least half of the year, inducing wide $\mathrm{T}$ and $\mathrm{RH}$ fluctuations (Figs. 5-7, Table 2). The areas primarily affected are the upper nave (3-5 $\mathrm{m}$ ) and the high altar, where RH may tumble by over $40 \%$ of the initial value and T may rise by up to $9^{\circ} \mathrm{C}$ while the heating is on $(1-2 \mathrm{~h})$. The conditions in the pews are less altered, with $\mathrm{T}$ increases of up to $4{ }^{\circ} \mathrm{C}$ and declines of no more than $20 \%$ initial RH. The heating also alters the indoor $\mathrm{T}$ and $\mathrm{RH}$ stratification, which becomes completely horizontal. The centre-west part of the church is impacted most intensely, with the highest RH and lowest T recorded in the lower nave, especially in the vicinity of the $\mathrm{N}$ wall, and the lowest $\mathrm{RH}$ and highest $\mathrm{T}$ in the upper SW and $\mathrm{W}$ nave (Fig. 8). After the heating is turned off, its cooling feature enables the $\mathrm{T}$ and $\mathrm{RH}$ to revert swiftly (25 minutes) to the initial values [30]. This system does not enhance human comfort at $40 \mathrm{~cm}$ (pews), for at that height the $\mathrm{T}$ rises to about $12-13^{\circ} \mathrm{C}$, from an initial $\mathrm{T}$ of $10-11^{\circ} \mathrm{C}$, and the RH barely varies (45-50\%). These perceptions were confirmed by persons attending the religious services. The $\mathrm{T}$ only climbs to $15-17^{\circ} \mathrm{C}$, improving thermal confort slightly, when the church is full (250-300 people/service), That is nonetheless still lower than the minimum operative temperature of $19^{\circ} \mathrm{C}$ suggested for wintertime heating ( $\left.\sim 1.0 \mathrm{clo}\right)$ in Category III buildings comparable to churches, and when metabolic activity is scant (1.2 met) [35]. At heights of over 3-5 m, where people are unaffected and conditions are governed by the heating system, the T rises to over $20^{\circ} \mathrm{C}$ and the $\mathrm{RH}$ may decline to $25 \%$, possibly compromising the conservation of the masonry and its timber coffered ceiling [30].

Ventilation and heating are not the only factors that induce fluctuations in the church interiors: the presence of a large congregation has the same effect. Clusters of people radiate heat and humidity, dispersing the $\mathrm{T}$ and concentrating the $\mathrm{RH}$ around them and affecting the entire indoor area. This effect on the indoor environment is substantial but sporadic and only present when the church is full (>300 peoples/service; confirmation, Christmas, Easter and local holidays).

In the first period (April-October 2011), the human impact was detected primarily in the pews (Figs. 6a and 6c) and sporadically in the choir (Fig. 6d) in the form of rises in the indoor T and RH (Fig. 9). In the area most densely occupied, the T climbs by up to $7^{\circ} \mathrm{C}$ (full church), but by only 2 - 
$3{ }^{\circ} \mathrm{C}$ in the peripheral areas with fewer people, the upper areas (3-5 $\mathrm{m}$ off the floor) and the high altar. Conversely, the RH tends to concentrate more in the periphery, the upper areas and the high altar. Close to the human cluster, then, T rises substantially but RH by only 1-10\% over the initial values. The latter increases more steeply (5-15\%) in the remaining parts of the church, where $\mathrm{T}$ slopes more moderately upward. These are the effects of human metabolism. The water vapour emitted in these processes is taken up into the environmental $\mathrm{RH}$, without inducing condensation in the environment or on the masonry walls or other surfaces, however. Such environmental conditions are not conducive to condensation in the atmosphere or on the masonry walls or other surfaces. The slanted stratification of the indoor temperature and relative humidity becomes horizontally and vertically concentric around the congregation, although close to the walls stratification is vertical due to the intensity of the effect of their thermal-hygrometric dynamics (Fig. 9).

The presence of people appears to be beneficial, especially when the heating is on in winter (second period, November 2011-April 2012). Table 2 shows that with the heating on, the RH and $\mathrm{T}$ are altered less in the pews than in the rest of the building. The presence of people when the church is heated tends to counter the steep declines in RH in the upper nave and the high altar, and depending on the number of people and where in the lower area of the nave they clusters, they may mitigate $\mathrm{RH}$ declines in such low areas to a greater or lesser degree (Table 2). As in the period discussed above, this is attributable to human metabolism. Where the congregation clusters, the humidity captured for respiration is offset by the emission of water vapour. Consequently, the decline in RH should be attributed more directly to the heating (Table 2(b), Fig. 10). Outside the area of human influence, the humidity generated by the water vapour emitted by respiration and transpiration concentrates, tapering the heating-induced decline in RH (Table 2(a), Fig. 10). At the same time, the presence of people may raise the environmental $\mathrm{T}$ in the lower nave $\left(2-5^{\circ} \mathrm{C}\right)$ more effectively than the heating system (Table 2, Fig. 10). The presence or absence of people has a scant effect on $\mathrm{T}$ in the upper nave and on the high altar; rather, the heating governs the $\mathrm{T}$ fluctuations in those areas. The horizontal stratification of environmental conditions, particularly $\mathrm{RH}$, during heating is barely altered in the presence of a full congregation (200-300 people/service; Fig. 10).

High RH and the steep fluctuations to which it may be subject make it a more critical parameter from the standpoints of heritage conservation and human comfort. Some authors [1, 4, 7, 12, 28] therefore suggest that RH should be held as stable as possible year round. While the RH values observed were not high (50\%) in the present case study, they did occasionally rise to $75 \%$ during the rainy spring and autumn periods and as a result of the moisture in the walls of the nave. Low RH (20-35 \%) values are common, however, both during the summer (warm and dry) and when the 
heating is on in the winter. They fluctuate widely with the natural seasons or sporadic inducements. The RH declines gradually in the early summer (20-30\%) and returns to values of $60-70 \%$ in the autumn. Where induced, however, the downturn is abrupt (25-40\%) and returns to the initial values shortly after the heating is turned off (45-60\%). According to the U.S. Environment Protection Agency (EPA), the optimal RH ranges from 30 to $50 \%$; according to Künzel [36], from 50 to $80 \%$; and according to Mecklemburgo et al. [37] and Schellen and Schijndel [38], from 40-45 to 70$75 \%$. Lower values cause respiratory problems as well as eye dryness and irritation (the dryer the environment, the greater the problems: $\mathrm{RH}<20 \%$ [35]) and physical and mechanical damage to masonry and works of art $(\mathrm{RH}<40-50 \%)$, while higher values ( $\mathrm{RH}>70-80 \%)$ favour the appearance of insects, mould or rot [38]. The lack of high indoor $\mathrm{RH}$, throughout the year explains the lack of condensation in the air or on church surfaces and hence the absence of biodeterioration. Low RH and its steep natural and induced fluctuations may generate internal stress on the surface of certain materials such as timber and plaster, due to iterated wet-dry cycles that govern their expansion and contraction [4, 10, 27, 36-40], in turn causing cracking, fissure(s), blistering and detachment. Such types of decay and deterioration are present in the lower nave up to a height of $1.5 \mathrm{~m}$ and on the high altar up to $0.5 \mathrm{~m}$. The materials affected in the main body are the gypsum plastering and on the high altar the dolostone and the masonry mortars. The polychrome plaster and timber sculptures show no signs of damage, as they lie beyond the area of influence of the rainwater filtrations and capillary moisture. The plaster and the timber coffering on the ceilings in the upper nave may be affected by drying cycles, primarily the cycles induced by the wintertime heating, for the low RH values induced by the heating concentrate in the upper areas of the church [30]. The time lag in material drying rates, attributable to their different heat capacities and the seasonality and sporadic nature of winter heating, leads to temporary insulation that in turn minimises decay $[30,34]$. Although no significant damage was detected in this study, timber swelling and contraction should be monitored to prevent the appearance of cracks.

The range of RH variation (30-70\%) observed may induce the saline solution mobility and salt precipitation on the surfaces of the indoor walls subject to intense moisture [14, 15, 27, 41, 42], since the RH at the base of the nave is altered less by the heating than by the church's natural dynamics and the effect of its construction materials. The presence of efflorescence (Ca sulphates; gypsum) is attributable primarily to the natural variations in the indoor environment, spring time ventilation and the presence of certain materials such as gypsum and cement mortars wall covering, and, and to a lesser extent, the use of heating. On the contrary, as the RH on the high altar is altered by both the heating and natural dynamics, the former may accentuate the presence of efflorescence (Ca-Mg sulphates; epsomite and hexahydrite) at the base of the walls. 
$\mathrm{CO} 2$ concentration is another indicator of indoor environmental conditions a building, and not only denotes the air quality $[12,16,25,35,43,44]$. It also induces surface dissolution that may affect alkaline materials such as plaster, stone and paint $[16,17]$. Concentrations of $400-600$ ppm were the values most commonly recorded in the empty church in the two monitoring periods, with and without heating. These values, which denote average indoor air quality (Category II [35, 44]), are an indication of that heating system combustion is satisfactory. In the presence of a congregation, however, the $\mathrm{CO}_{2}$ concentration rose to $600-1000 \mathrm{ppm}$, which is tantamount to moderate indoor air quality (Category III [35, 44]). Values of over 1000 ppm were reached when the church was full ( $>300$ people/service) lowering indoor air quality to Category IV $[35,44]$. Such extreme values, recorded only occasionally, generate a stuffy atmosphere and possible discomfort in the form of odours, headaches and minor respiratory problems [35, 43, 44]. The highest $\mathrm{CO}_{2}$ levels were detected in the summer time (August-September 2011) when human presence was most intense during services. In that season, it took from 1 to 3 hours for the indoor $\mathrm{CO}_{2}$ concentration to rise (+ 450-550 ppm / 100-150 people or $+650-750 \mathrm{ppm} / 300$ people or over) and from 2 to 4 hours to return to normal values (400-600 ppm). In other words, the effective ventilation rate [44] was 4.3 to 6, although it rose to 12.7 when $\mathrm{CO}_{2}$ concentration was $>1200 \mathrm{ppm}$. In the winter (December 2011January 2012) in contrast, it only took around 30 minutes for the $\mathrm{CO}_{2}$ concentration to rise $(+200$ $250 \mathrm{ppm} / \sim 50$ people or $+450-500 \mathrm{ppm} / 200-250$ people), and up to 6 hours to return to the normal 450-550 ppm. In ths case, the effective ventilation rate [44] was less, 1.7-4. The rise in $\mathrm{CO}_{2}$ inside the church is the direct result of human metabolism and the building's scant ventilation during religious services, particularly in the winter when natural ventilation was less effective.

The absence of surface dissolution in any of the church's architectural or artistic element can be attributed to $\mathrm{RH}$ levels that remain consistently below the threshold ( $>80 \%$ ) needed to induce surface condensation and to $\mathrm{CO}_{2}$ concentrations that only very occasionally climb to the $>750 \mathrm{ppm}$ required to acidify water vapour $(\mathrm{pH} \sim 5.6)[12,16,17,45]$. These findings are very important for the indoor heritage conservation.

\section{Conclusions}

- The natural indoor environment in this church is subject to wide daily and seasonal differences in the outdoor climate and the moisture in the nave walls. The indoor mean RH is not high $(\sim 50 \%)$.

- The natural factors that alter this indoor environment are aggravated by the disturbance induced by daily ventilation, heating in the winter (November-April) and the presence of people. 
- Daily ventilation $(10 \mathrm{~h})$ to reduce the damp at the base of the walls induces minor fluctuations, primarily in the RH in the lower nave. Such fluctuations are observed in spring essentially, when the difference between the indoor and outdoor conditions is greatest.

- Ventilation in the spring and the effect of the outdoor climate govern the decay and deterioration detected at the bottom of the indoor walls (drying processes that lead to gypsum efflorescence and plaster blistering and detachment).

- Heating in the church in the winter induces steep and abrupt changes in the indoor environment that primarily affect the upper nave and the high altar. In contrast, these fluctuations are less intense and scantly significant in the pews.

- Heating mainly affects RH, lowering its value temporarily and intermittently to below $25 \%$. While these values are also reached in the summer due to outdoor conditions, the declines are more stable and more gently sloped. The result is that, primarily when the heating is on in the winter, the scant humidity may cause minor problems for certain people and deterioration of the timber in the coffered ceiling as well as the plaster (drying shrinkage that induces surface cracking) in the upper nave and on the carved dolostone ashlars (epsomite ans hexahydrite efflorescences) of the high altar. No severe damage is caused in either material because of the short duration and scant iteration of the fluctuations (1-2 h), given the sporadic use of the church.

- The presence of people inside the church affects its natural and induced environments. Human metabolism radiates heat and humidity, which are taken up into the church atmosphere. The increase in $\mathrm{T}$ is dispersed radially as it flows away from the source, while $\mathrm{RH}$ rises.

- The presence of a large congregation tends to attenuate the steep heating-induced declines in $\mathrm{RH}$, particularly beyond the influence of the human source of humidity, and to enhance thermal comfort within the cluster of people, where the warm air from the heating and the heat generated by the human body reinforce one another.

- The indoor levels of $\mathrm{CO}_{2}$ are due to human metabolism, not to the heating system. The highest levels $(>1000 \mathrm{ppm})$ are recorded in the summer when the church has a larger congregation, but these concentrations entail no risk either for human health or the indoor heritage. Human health is unaffected due to the brevity of religious services and because daily ventilation is sufficient. Nor do these levels generate surface dissolution that might affect the indoor heritage because the RH in that season is low and high levels of $\mathrm{CO}_{2}$ are reached only sporadically.

The major recommendation for conserving this church's indoor artistic and architectural heritage while affording greater human comfort is to solve the moisture problems in its walls. That would 
contribute to stabilising the indoor RH. Care should be exercised as the church is ventilated daily, avoiding steep contrasts with the outdoor conditions, for such precautions would narrow the wide fluctuations in $\mathrm{RH}$ in certain areas of the church and thereby retard the decay and deterioration of its surface materials. The heating system is ageing and scantly effective (Spanish and European standard UNE-EN 15759-1), from the standpoints the asset conservation. It should either be replaced or its use restrained, controlling ventilation in the upper areas of the church and making certain changes in the facility, such as: a) disabling the vent connection to the outdoors to prevent cold damp air from entering the church when the heating is off (severe disturbance); b) repositioning the vents at lower wall heights and redirecting them so the warm air flows out closer to the floor, to enhance congregation comfort and minimise disturbance; and c) lowering the pre-heat $\mathrm{T}$ of the air flow emitted by the system (severe disturbance).

\section{Acknowledgements}

This study was funded under projects CGL2010-19554 and CGL2011-27902 and forms part of the GEOMATERIALES (S2009/MAT-1629) research programme. The authors are members of the Complutense University of Madrid's Research Group: “Alteración y Conservación de los Materiales Pétreos del Patrimonio” (ref. 921349). Thanks are owed to the Archbishopric of Alcalá de Henares, Madrid, and all the persons associated with the church in Talamanca for their assistance throughout this study. Part of the research was supported by a PICATA pre-doctoral fellowship awarded by the Moncloa Campus of International Excellence (UPM-UCM, CSIC) and the JAEPreDoc fellowship/European Social Fund FSE 2007-2013 Adaptability and Employment programms. Manuscript edited by Margaret Clark, professional translator and English language science editor.

\section{References}

[1] Camuffo D. Microclimate for Cultural Heritage. Developments in Atmospheric Science 23, Amsterdam Elsevier; 1998, 415 p.

[2] Camuffo D. The friendly heating Project and the conservation of the cultural heritage preserved in Churches, In: Kilian R, Vyhlídal T, Broström T, editors. Developments in Climate Control of Historic Buildings, Fraunhofer IRB Verlag, Stuttgart; 2011, p. 7-12.

[3] Olesen BW. International standards for the indoor environment. Indoor Air 2004; 14 (7): 18-26.

[4] Bratasz L, Kozlowski R. The CEN TC346 draft standard on heating historic churches: minimizing disturbance to the indoor climate. In: Klimagestaltung im Spannungsfeld zwischen Kulturguschutz und 
Nutzerwünschen, Tagungsblatt des 1. Konservierungswissenschaftlichen Kolloqiums, Berlin; 2007, p. 24-31.

[5] Bernardi A. Microclimate Inside Cultural Heritage Buildings. Ed il Prato, Padova; 2008, 171 p.

[6] Camuffo D, Pagan E, Bernardi A, Becherini F. The impact of heating, lighting and people in re-using historical buildings: a case study. Journal of Cultural Heritage 2004; 5: 409-416.

[7] Camuffo D, Pegan E, Rissanen S, Bratasz L, Kozlowski R, Camuffo M, della Valle A. An advanced church heating system favorable to artworks: A contribution to European standardization. Journal of Cultural Heritage 2010; 11 (2): 205-219.

[8] Balocco C. Daily natural heat convection in a historical hall. Journal of Cultural Heritage 2007; 8: 370376.

[9] Camuffo D, Pagan E, Schellen HL, Limpens-Neilen D, Kozlowski R, Bratasz L, Rissanen S, Van Grieken R, Spolnik Z, Bencs L, Zajaczkowska-Kloda J, Kloda P et al. Church heating and preservation of the cultural heritage: a practical guide to the pros and cons of various heating systems. In: Il riscaldamento nelle chiese e la conservazione dei beni culturali: guida allfanalisi dei pro e dei contro dei vari sistemi di riscaldamento. Milano, Electa Mondadori; 2007, 240 p.

[10] Schelle HL. Heating Monumental Churchs-Indoor Climate and Preservation of Cultural Heritage. PhD thesis, Technical University of Eindhoven, The Netherlands; 2002, 228 p.

[11] Kramer R, Van Schijndel J, Schellen H. Inverse modeling of simplified hygrothermal building models to predict and characterize indoor climates. Building and Environment 2013; 68: 87-99.

[12] Camuffo D. Microclimate for Cultural Heritage. Conservation, Restoration and Maintenance of Indoor and Outdoor Monuments. 2nd Edition. Amsterdam: Elsevier Science; 2014, 519p.

[13] Price C. Predicting environmental conditions to minimise salt damage at the Tower of London: a comparison of two approaches. Environmental Geology 2007; 52 (2): 369-374.

[14] López-Arce P, Fort R, Gómez-Heras M, Pérez-Monserrat E, Varas-Muriel MJ. Preservation strategies for avoidance of salt crystallisation in El Paular Monastery cloister, Madrid, Spain. Environmental Earth Sciences 2011; 63 (7-8): 1487-1509.

[15] Lopez-Arce P, Garcia-Guinea J, Benavente D, Tormo L, Doehne E. Deterioration of dolostone by magnesium sulphate salt: An example of incompatible building materials at Bonaval Monastery, Spain. Construction and Building Materials 2009; 23 (2): 846-855.

[16] Bencs L, Spolnik Z, Limpens-Neilen D, Schelle HL, Jütte B, Van Grieken R. Comparison of hot-air and low-radiant pew heating systems on the distribution and transport of gaseous air pollutants in the mountain church of Rocca Pietore from artwork conservation points of view. Journal of Cultural Heritage 2007; 8 (3): 264-271. 
[17] Vuerich E, Malaspina F, Barazutti M, Georgiadis T, Nardino M. Indoor measurements of microclimate variables and ozone in the church of San Vincenzo (Monastery of Bassano Romano-Italy): A pilot study. Microchemical Journal 2008; 88 (2): 218-223.

[18] Frontczak M, Wargocki P. Literature survey on how different factors influence human comfort in indoor environments. Building and Enviroment 2011; 46: 922-937.

[19] Humphreys MA, Rijal HB, Nicol JF. Updating the adaptive relation between climate and comfort indoors; new insights ans an extended database. Building and Environment 2013; 63: 40-55.

[20] Tabunschikov Y, Brodatch M. Indoor air climate requirements for Russian and cathedrals. Indoor Air 2004; 14 (7): 168-174.

[21] Kavgic M, Mumovic D, Stevanovic Z, Young A. Analysis of thermal comfort and indoor air quality in a mechanically ventilated theatre. Energy and Buildings 2008; 40: 1334-1343.

[22] Bichlmair S, Kilion R. Room climate in Linderhof Palace. In: Kilian R, Vyhlídal T, Broström T, editors. Developments in Climate Control of Historic Buildings, Fraunhofer IRB Verlag, Stuttgart; 2011, p. 5360.

[23] Camuffo D, Van Grieken R, Busse HJ, Sturaro G, Valentino A, Bernardi A, Blades N, Shooter D, Gysels K, Deutsch F, Wieser M, Kim O. Environmental monitoring in four European museums. Atmos. Environ. 2001; 35: S127-S140.

[24] La Gennusa M, Rizzo G, Scaccianoce C, Nicoletti F. Control of indoor environments in heritage buildings: experimental measurements in an old Italian museum and proposal of a methodology. Journal of Cultural Heritage 2005; 6: 147-155

[25] Larsen PK, Broström T. Climate control in cultural Heritage buildings in Denmark. In: Kilian R, Vyhlídal T, Broström T, editors. Developments in Climate Control of Historic Buildings, Fraunhofer IRB Verlag, Stuttgart; 2011, p. 39-44.

[26] Rohdin P, Dalewski M, Moshfegh, B. Indoor environment and energy use in historic buildings comparing survey results with measurements and simulations. International Journal of Ventilation 2012; 10 (4): $371-382$.

[27] Larsen PK. Climate control in Danish churches. In: Padfield T, Borchersen K, editors. Museum Microclimates. National Museum of Denmark; 2007.

[28] Schellen HL, Neuhaus E. Conservation heating in a Historical building: Results from an experimental and simulation study. In: Kilian R, Vyhlídal T, Broström T, editors. Developments in Climate Control of Historic Buildings, Fraunhofer IRB Verlag, Stuttgart; 2011, p. 21-27.

[29] UNE-EN 15759-1. Conservation of cultural property, Indoor climate, Part 1: Guidelines for heating churches, chapels and other places of worship, AENOR, Madrid, España; 2012. 
[30] Varas-Muriel MJ, Martínez-Garrido MI, Fort R. Monitoring the thermal-hygrometric conditions induced by traditional heating systems in a historic Spanish church $\left(12^{\text {th }}-16^{\text {th }}\right.$ C. $)$. Energy and Buildings 2014; 75: 119-132.

[31] Martínez-Garrido MI, Fort R, Varas-Muriel MJ. Analysis of heating systems effectiveness and efficiency in Spanish churches. Applied Energy, in review.

[32] Fort R, Álvarez de Buergo M, Pérez-Monserrat E, Gómez-Heras M, Varas-Muriel MJ, Freire DM. Evolution in the use of natural building stone in Madrid, Spain. Quarterly Journal of Engineering Geology and Hydrogeology 2013; 46: 421-429.

[33] Fort R, Fernández-Revuelta B, Varas MJ, Álvarez de Buergo M, Taborda M. Influencia de la anisotropía en la durabilidad de las dolomías cretácicas de la Comunidad de Madrid frente a la cristalización de sales. Materiales de Construcción 2008; 58: 289-290 and 161-178.

[34] Martínez-Garrido MI, Aparicio S, Fort R, Anaya JJ, Izquierdo MAG. Effect of Solar Radiation and Humidity on the inner core of walls in historic buildings. Construction and Building Materials 2014; 51: 383-394.

[35] UNE-EN 15251. Indoor environmental input parameters for design and assessment of energy performance of buildings addressing indoor air quality, thermal environment, lighting and acoustics. AENOR, Madrid, España; 2008.

[36] Künzel H. Bauphysikalische Untersuchungen in Unbeheizten und Beheizten Gebäuden alter Bauart. Fraunhofer-Institut für Bauphysik, nº FB-32- Stuttgart: IRB-Verlag; 1991.

[37] Mecklenburg MF, Tumosa CS, Erhardt D. Structural response of painted wood surfaces to changes in ambient relative humidity. Painted Wood, History and Conservation. The Getty Conservation Institute; 1998, p. 464-483.

[38] Schellen HL, Van Schijndel JAWM. An overview of experimental and simulation work on indoor climate and control in historic houses and monumental buildings. In: Contribution to the Experts' Roundtable on Sustainable Climate Management Strategies. Getty Conservation Institute. Tenerife, Spain; 2007, 47 p.

[39] Samek L, de Maeyer-Worobiec A, Spolnik Z, Bencs L, Kontozova V, Bratasz L, Kozlowski R, Van Grieken R. The impact of electric overhead radiant heating on the indoor environment of historic churches. Journal of Cultural Heritage 2007; 8 (4): 361-369.

[40] Varas MJ, Álvarez de Buergo M, Pérez-Monserrat E, Fort R. Decay of the restoration render mortar of the church of San Manuel and San Benito, Madrid, Spain: Results from optical and electron microscopy. Materials Characterization 2008; 59 (11): 1531-1540.

[41] Sawdy A, Price C. Salt damage at Cleeve Abbey, England. Part I: a comparison of theoretical predictions and practical observations. Part II : seasonal variability of salts distribution and implications for sampling strategies. Journal of Cultural Heritage 2005; 6: 125-135 and 361-367. 
[42] Sawdy A, Heritage A. Evaluating the influence of mixture composition on the kinetics of salt damage in wall paintings using time lapse video imaging with direct data annotation. Environmental Geology 2007; 52: 303-315.

[43] ASHRAE standard 62. Ventilation for Acceptable Indoor Air Quality. Atlanta GA, American Society of Heating, Refrigerating and Air Conditioning Engineer, USA; 2001.

[44] UNE-EN 13779. Ventilation for non-residential buildings - Performance requirements for ventilation and room-conditioning systems. AENOR, Madrid, España; 2008.

[45] Bonazza A, Messina P, Sabbioni C, Grossi CM, Brimblecombe P. Mapping the impact of climate change on surface recession of carbonate buildings in Europe. Science of the Total Environment 2009; 407: 2039-2050.

\section{TABLES AND FIGURES LEGENDS.}

Fig. 1. San Juan Bautista Church (twelfth-sixteenth centuries), Talamanca de Jarama, Madrid, Spain

Fig. 2. NE corner of the church. The convection vents for the heating system are positioned at $3 \mathrm{~m}$ from the floor on the north wall of the north aisle.

Fig. 3. Sensor positions inside and outside the church

Table 1. Indoor and outdoor environmental conditions in the church during the 13 months of the monitoring period

Fig. 4. Variations in mean RH and T, outdoors and in three indoor areas (nave at heights of $40 \mathrm{~cm}$ and 3-5 $\mathrm{m}$, and the high altar) during the 13-month monitoring period

Fig. 5. Variation in RH (a) and T (b): mean maximum, mean and mean minimum values in the three indoor areas monitored for 13 months

Fig. 6. Variation in environmental conditions (RH, T, DP and AbsHum) at $40 \mathrm{~cm}$ and 3-5 $\mathrm{m}$ in the $\mathrm{NE}$ and $\mathrm{W}$ areas of the church

Table 2. RH losses and $\mathrm{T}$ gains in the three areas of the church monitored, under different conditions in the month of December, during periods of time ranging from 2.5 to $22 \mathrm{~h}$

Fig. 7. Daily variations in RH and T at $40 \mathrm{~cm}$ and $3-5 \mathrm{~m}$ in the heated church (November 2011April 2012) and comparison to the variations in the unheated church (April-October 2011)

Fig. 8. Plan view at heights of $3-5 \mathrm{~m}$ and $40 \mathrm{~cm}$ and cross-section (E and $\mathrm{W}$ areas) of $\mathrm{RH}$ and $\mathrm{T}$ distributions in the heated church with no congregation: 2 December 2011 
Fig. 9. Plan view at a height of $40 \mathrm{~cm}$ and cross-section (W area) of $\mathrm{RH}$ and $\mathrm{T}$ distributions in the unheated church with a full congregation: confirmation, 9 April 2011

Fig. 10. Plan view at a height of $40 \mathrm{~cm}$ and cross-section ( $\mathrm{W}$ area) of $\mathrm{RH}$ and $\mathrm{T}$ distributions in the heated church with a full congregation: Christmas, 25 December 2011 